\title{
地方都市における高齢者の居住環境評価に関する研究 \\ 一生活関連施設立地からみた地域構造分析一 \\ A STUDY ON THE EVALUATION METHODOLOGY OF LIVING ENVIRONMENT FOR THE ELDERLY PEOPLE IN LOCAL CITY
}

Analysis of regional structure from the point of view of facilities for daily living

野原康弘*, 佐藤栄治**, 三橋伸夫***

Yasuhiro NOHARA, Eiji SATOH and Nobuo MITSUHASHI

\begin{abstract}
The purpose of this study is to obtain the knowledge about the assessment methodology of present environmental condition for the elderly people in residential area. And the methodology will be able to judge the future situation whether the residential area would be habitable.

We analyze the characteristics of the local, Nasushiobara city in Tochigi. And to use GIS and to calculate the physical environment clarified the situation of local areas quantitatively.

As the results of the analysis, we made sure of distribution of the accessibility between the urban area and the agricultural and mountainous rural area. The most accessible facility is "bus-stop", and the agricultural and mountain area have relatively low accessibility. The worst accessible facility is "medical institution". Distribution of accessibility with regard to police station and post office is low.
\end{abstract}

Keywords: the evaluation methodology of living environment, elderly people, local city, regional structure 居住環境評価, 高齢者, 地方都市, 地域構造

1. はじめに

\section{2 研究の背景と目的}

2014 年現在, 我が国の高齢者人口（65 歳以上）は 3,190 万人で, 総人口に占める割合（高齢化率）は $25.1 \%$ となり世界に類を見ない 速度で超高齢社会を迎えている ${ }^{1)}$ 。我が国では，今後とも長期的に人 口減少が続き，高齢化傾向はますます進行するとされている，そし て 2035 年には高齢化率は $33.4 \%$ ，つまり国民の 3 人に 1 人が 65 歳以 上となると推計されている ${ }^{2)}$.

人口構造変化による高齢者サービスに対するニーズの増加は，医 療・介護体制や行政サービスの提供方法などへ影響を与えている. 高齢社会に適応した医療・介護関連産業の開拓が積極的に行われ， 自立生活を地域における医療と介護の連携により支援する地域包括 的ケアシステムへの取り組みが模索されている ${ }^{3)}$. 特に, 介護予防と 日常生活支援を対象とした地域支援事業に重点が置かれ，買い物支 援や移送サービス等の地域の高齢者ニーズを反映したケアの仕組み の構築が急がれている。また，人口減少時代を迎え社会資本の大幅 な増進が望めない我が国においては，行政サービスを各地域の寸み ずみまで十分に行き渡らせることは困難であり, それによって生じ 得る地域間格差への対策が必要である. 現在, 地方都市における高 齢化傾向は大都市に比べて著しく, 財政状況は逼迫している.また,
大都市と地方都市間の格差だけでなく地域内格差（地区間格差）も 顕在化しており，社会保障給付をはじめとする行政サービスの持続 可能性を考慮した対策を迫られている.

こうしたことから, 近年では, 高齢者の居住環境注 ${ }^{1)}$ を適切に分析・ 評価し居住環境の問題点を明らかにすることで，今後の行政サービ スの在り方を検討する上で有益な研究 ${ }^{4), 5), 6)}$ が数多く行われている. 特に, 高齢者の居住地と施設間の物理的な移動距離（以下, アクセ シビリティ）からみた居住環境の分析・評価に関する研究は，人口 減少時代を迎え社会資本の増進が望めない我が国において重要であ ると考える.また，効率的な行政サービスを提供するには，現状の 地域資源でカバーできる利用者数をアクセシビリティの観点から事 前に把握し，それを基にサービス量と提供方法について検討してい くことが重要であると考える.

そこで, 本研究では, 高齢者の「居住地 - 施設間」のアクセシビリティ に着目した居住環境分析を行い, 高齢者の生活関連施設の利用にお ける距離的格差を把握することで, 現状の居住環境を定量的に評価 し, 居住環境の地域内格差を明らかにする手法の開発に向けた一助 とすること目的とする.

\section{2 研究の位置づけ}

人口分布や施設配置からみた地域の利便性 ${ }^{77,8), 9)}$ や施設の適正配置
* 宇都宮大学大学院工学研究科システム創成工学専攻 博士後期課程

** 宇都宮大学大学院工学研究科 准教授 ·博士 (工学)

*** 宇都宮大学大学院工学研究科 教授. 工博
Grad. Stud., Graduate school of Engneering, Utsunomiya Univ., M.Eng

Assoc. Prof., Graduate school of Engneering, Utsunomiya Univ., Dr.Eng Prof., Graduate school of Engneering, Utsunomiya Univ., Dr.Eng 
10)，11，12)をもとに居住環境を分析・評価した幾多の既往研究の中で, 本研究に関係する生活関連施設へのアクセシビリティ分析・評価に 関寸る先行研究を踏まえ, 本研究の特徴について述べる.

増山は ${ }^{13)}$ ，商業施設と医療施設へのアクセシビリティと高齢者の 居住パターンとの関係に着目し, 直線距離と道路距離を用いて, 高 齢者の居住環境における施設と居住分布との近接性の関係を分析し ている. 生活関連施設を包括的に扱った研究としては山岸ら ${ }^{14)}$ や佐 藤ら ${ }^{15)}$ の研究がある. 山岸らは, 直線距離でみた徒歩圈内でのアク セシビリティにもとづいた生活利便性をスコア化し, それらを地図 に落とし込み視覚化することで居住環境の把握と評価を行っている. 佐藤らは, 高齢者の居住地から生活関連施設までのアクセシビリティ に着目し，直線距離でみた徒歩圈内における居住環境を分析し，そ れを基に居住環境の評価水準の作成を試みている.

これらの研究に対して, 本研究では佐藤ら ${ }^{15)}$ の先行研究を進展さ せ，様々な生活関連施設を包括的に扱い，道路距離を用いたアクセ シビリティ分析を行うことで，地域における高齢者の居住環境の特 性について考察する. 道路距離を用いた施設立地のアクセシビリティ に関する分析 $\left.{ }^{16)}, 17\right)$ は近年盛んに行われているが，その中で高齢者の 生活を支える様々な生活関連施設を包括的に扱った研究は他に見ら れない.

また，先に述べたように，行政サービスの地域内格差や持続可能 性などが問題視される現状において，高齢者の居住地に配慮した効 率的なサービス提供方法の構築といった考えも今後必要となる可能 性がある。こうした視座に立ち，本研究では，徒歩圏でのアクセシ ビリティ分析に加えて, 地域のおおよその高齢者のアクセシビリティ の傾向を把握するための仮想的な圈域（ $80 \%$ 距離圈：説明は後述） を設定し分析を行うことで，地域資源を活用した効率的な行政サー ビスの在り方を探るための知見を得る。

\section{2. 研究方法}

本研究では，地理情報システム（GIS）を用いて生活関連施設への アクセシビリティの観点から居住環境分析を行い，高齢者の居住環 境の問題を明らかにする.

\section{1 対象地域の概要}

本研究では，人口減少や少子高齢化などの人口構成の変化が進む

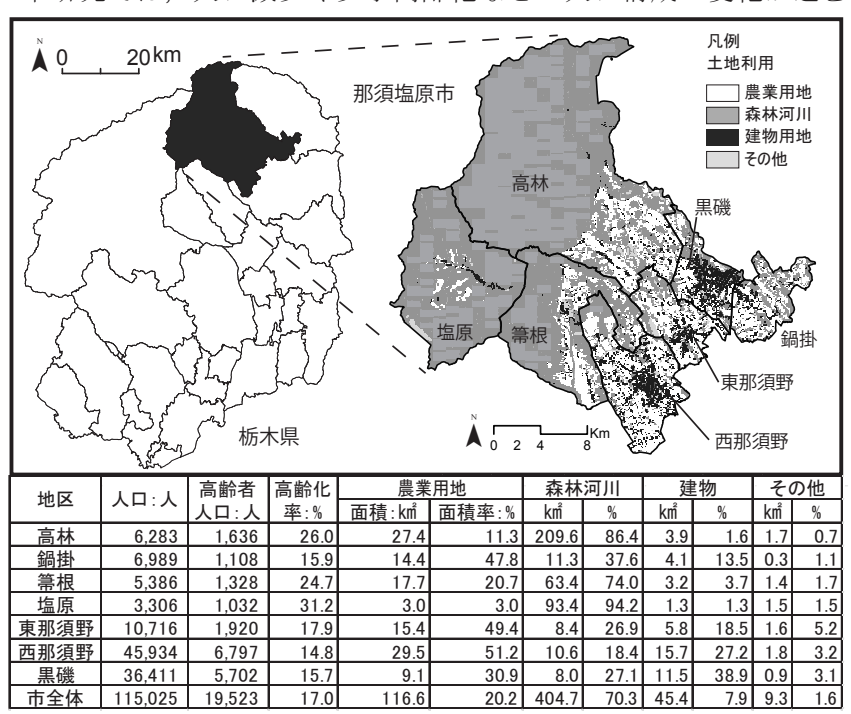

図 1 那須塩原市の 7 地区と土地利用
地方として栃木県を取り上げ，その栃木県北部に位置し，様々な課 題を抱える地方都市として栃木県那須塩原市を取り上げた。那須塩 原市の人口は約 11 万 6 千，高齢者人口は約 2 万 3 千である（平成 22 年国勢調查)。山間部之扇状地で形成された農村部・市街地部からな る地方都市であり，アクセシビリティの悪化が懸念される山間部や 農村部と，アクセシビリティが高いと考えられる市街地部とが混在 寸ることから，アクセシビリティの地域内格差を比較し分析する上 で適切な地域であると判断し当該地域を研究対象とした。当該地域 では，独居高齢者や高齢者のみの世帯の増加に伴い介護サービスへ の需要の増加が予測されることから, 地域見守り支え合い体制構築 や地域包括支援センターの機能・運営の強化など，住み慣れた地域 での暮らしの実現に向けて高齢者福祉計画が推進されている ${ }^{18)}$.

\section{2 対象地域の土地利用と人口分布}

居住環境を分析していくにあたって，対象地域の土地利用と人口 分布を明らかにした。土地利用は, 国土数值情報の土地利用細分メッ シュデータ（平成 21 年度時点）を基に作成した。地区は都市計画マ スタープラン ${ }^{19)}$ を参考に 7 地区に分けた（図 1)。[黒磯. 西那須野] 地区は建物用地が多く市街地が形成されている。 [ 鍋掛, 東那須野 ] 地区は，農業用地が多くを占める市街地近郊の農村部である。[高林, 篣根, 塩原］地区は, 農業用地と森林河川からなる農村・山間部である. 図 2 は, 平成 12 年度から平成 22 年度の人口と高齢化率の推移を表 している ${ }^{\text {注 } 2)}$. [黒磯. 西那須野, 東那須野] 地区では人口増加傾向に ある，高齢化率は，[高林，篣根，塩原］地区では高く，特に［塩原］ 地区では急激に上昇している。[黒磯．西那須野，東那須野，鍋掛] 地区では $20 \%$ 以下に留まっているが，その中でも［黒磯］地区は他 の 3 地区に比べて高齢化の進行が速い, 以上より, 対象地域は農村 · 山間部では高齢化率が高く, 市街地と市街地近郊では高齢化率が比 較的低くなっていることから，地方都市の高齢化傾向を示した典型 的な例であると言える。

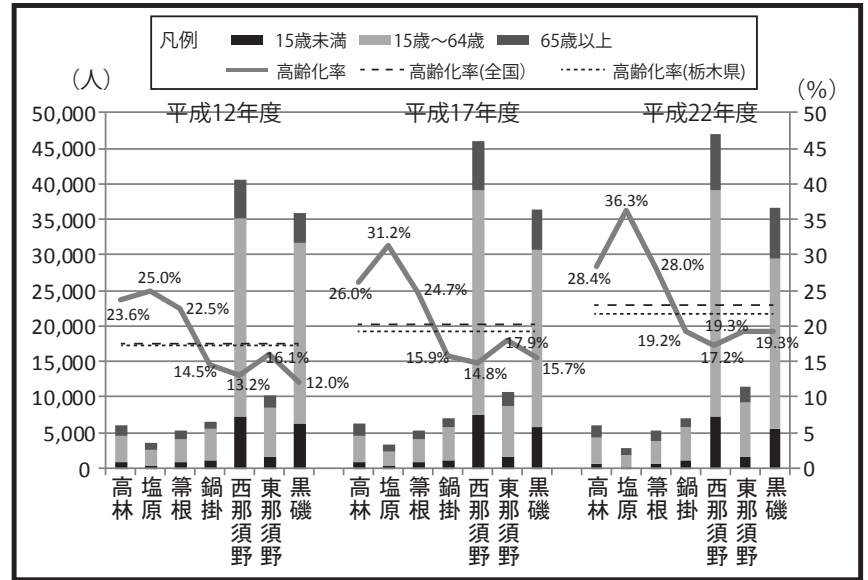

図 2 人口と高齢化率の推移

表 1 生活関連施設の 5 分類 14 種

\begin{tabular}{|c|c|c|c|c|c|}
\hline 分類 & 施設 & 詳細 & 数 & 出典 & 情報収集期間 \\
\hline \multirow{4}{*}{ 購買 } & コンビニエンスストア & & 50 & \multirow{13}{*}{ iウウンページ } & \multirow{13}{*}{ 2012/7～8月 } \\
\hline & 食料品店 & 食料品，食肉，青果物等 & 154 & & \\
\hline & 日用品店 & 日用雑貨，金物，めがね等 & 84 & & \\
\hline & 複合商業施設 & デパート, スーパー- & 34 & & \\
\hline \multirow{2}{*}{$\begin{array}{l}\text { 生活 } \\
\text { 財務 }\end{array}$} & 郵便局 & & 22 & & \\
\hline & 銀行 & & 13 & & \\
\hline \multirow{2}{*}{ 安全 } & 警察署 & & 12 & & \\
\hline & 消防署 & & 4 & & \\
\hline \multirow{5}{*}{ 医療 } & 内科 & \multirow{4}{*}{ 病院, クリニック } & 37 & & \\
\hline & 整形外科 & & 12 & & \\
\hline & 歯科 & & 42 & & \\
\hline & 眼科 & & 4 & & \\
\hline & 第三次救急医療機関 & 大田原赤十字病院 & 1 & & \\
\hline 交通 & バス & バス停 & 243 & 国土数値情報 & 2013/1月 \\
\hline
\end{tabular}




\section{3 居住環境分析の方法}

アクセシビリティの視点から, 高齢者の居住環境を分析するに際 して, 生活関連施設と高齢者の居住地との道路ネットワーク距離（以 下, 道路距離) を用いた。本研究では, 現在整備されている道路デー タをもとに, 生活関連施設と高齢者の居住地との最短道路距離を計 測することにより，従来からよく利用されている直線距離 ${ }^{12)}{ }^{15}$, 20) に 比べて, より生活実態に即したアクセシビリティ分析が行えると考 える.

\section{1 ) 対象施設の設定}

高齢者の地域居住に最低限必要となると考えられる施設を生活関 連施設として「購買, 生活財務, 安全, 医療, 交通」の 5 分野を想 定し, 表 1 に示寸 5 分野 14 種の施設を設定した。本研究は，施設選 択を考慮した詳細な利便性ではなく，簡易的に施設へのアクセス可 能性に焦点を当てるため, 利用頻度や施設規模, 取り扱う品物の種類・ 数などは考慮していない注3)。「交通」分野に関しては, 必要最低限の 生活行動という観点から, 広域移動ではなく地域内での移動を想定 し，徒歩でアクセスし利用できる交通拠点としての「バス停」のみ を設定した ${ }^{\text {i } 4)}$ 。また, 「安全」分野に関しては, 他の分野がサービス 利用者側からの分析・評価となるのに対して, 当分野はサービス提 供者側からの視点となる。これに関しては 3 章， 4 章において，サー ビス利用者側とサービス提供者側の二つの視点から分析・評価を行 う。なお，生活関連施設に関する立地情報はｉタウンページと国土 数值情報により収集し（表 1)，CSV アドレスマッチングサービス注5) により街区・地番レベルの緯度・経度情報を取得した。取得した緯度・ 経度情報の中で精度の低い施設については, Google マップ上で施設 の座標を拾い直し分析に使用した。

\section{2 ) 施設利用者の設定}

高齢者の生活実態に即した分析を行うには，厳密には利用者の居 住地を把握しなければならないが，現時点では情報公開に限界があ り困難である. 本研究では, 人口の過密度合が把握できる国勢調査 基本単位区データを用い, GIS 上で分析を行った。 高齢者人口につい
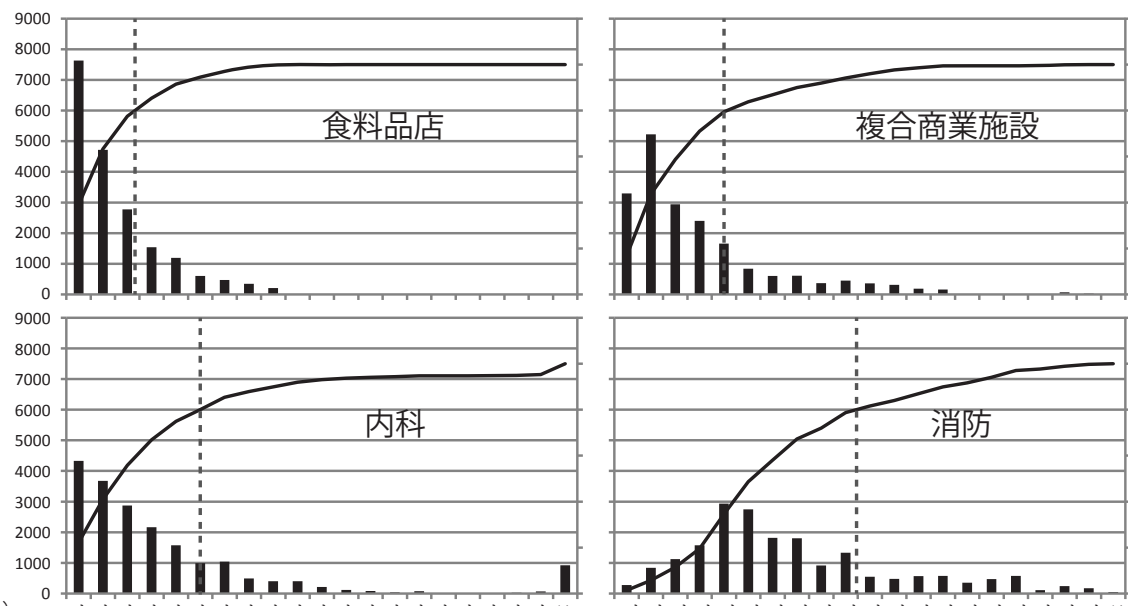

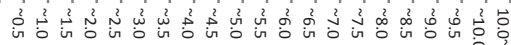

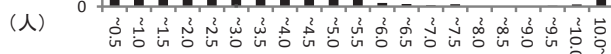

ては, 平成 17 年国勢調查の基本単位区集計人口に小地域人口データ の年齢構成比を割り当てることにより高齢者人口を算出した．基本 単位区集計は公開されている最小の人口集計単位であり，都市とい うマクロなレベルにおいて詳細な分析が可能であると考える ${ }^{21)}$ 注6).

\section{3 ) 分析の前提}

分析の前提として, 生活関連施設と居住地の住所データを緯度・ 経度情報に変換した後 GIS の電子地図上に読み込み, さらに ArcGIS Network Analyst を用いてアクセシビリティを定量的に分析した。道 路データには国土数值情報を 2012 年 8 月現在の道路状況に合わせて 加工したものを用いた。 また, 生活関連施設へのアクセス手段とし て徒歩や自動車での移動に配慮して幅員 $1.5 \mathrm{~m}$ 以上の道路データを用 いた ${ }^{\text {i注 }}$.

高齢者の居住環境をアクセシビリティにより分析するに際して, i : 徒歩圈人口（以下, T人口）の分布, ii : $80 \%$ 人口距離圈（以下, P 圈) および $20 \%$ 人口（以下, P 圈外人口) の分布, という各施設に 関する 2 つ指標をもとに分析する，iのT人口の分布では，高齢 者の徒歩生活圈として, OECD の調查結果 ${ }^{23)}$ と公共交通指向型開発 (TOD:Transit Oriented Development) を参照し $600 \mathrm{~m}$ を採用した。各生 活関連施設から道路距離で $600 \mathrm{~m}$ の範囲に居住する高齢者人口を G IS により計測することで，徒歩で施設を利用できる高齢者人口を明ら かにした。 ii のP 圈とP 圈外人口の分布に関しては，全市的な高齢 者に対する施設立地の充足度を把握するための仮想的なレベルを設 けることにした，仮に高齢者の日常生活における生活関連施設利用 が居住地を基準とした最近隣施設であるとしたとき，大多数の高齢 者人口をカバーする範囲の閾值として「 $80 \%$ 人口距離圈 : P 圈」を設 定した。これは, 各生活関連施設から高齢者居住地までの道路距離 毎に集計した人口を近い距離から加算していき, 累積比率が高齢者 人口の $80 \%$ に到達したときの距離圈を示している. また，P 圈外に存 在する残り $20 \%$ の人口を「 $20 \%$ 人口：P 圈外人口」とし，大多数の高 齢者に比べて生活関連施設利用が困難であると考え得る高齢者を定 量的に把握することとした。

図 3 距離帯別人口分布と累積比率

表 2 施設ごとの距離動向 ※中央值は，データを大きさ順に並べたときの真ん中に位置する值

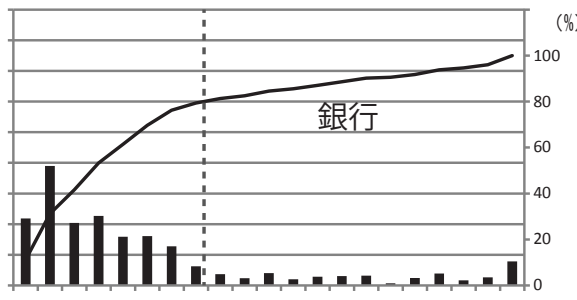

\begin{tabular}{|c|c|c|c|c|c|c|c|c|c|c|c|c|c|c|}
\hline 分野 & \multicolumn{4}{|c|}{ 購買 } & \multicolumn{2}{|c|}{ 生活財務 } & \multicolumn{5}{|c|}{ 医療 } & \multicolumn{2}{|c|}{ 安全 } & 交通 \\
\hline 施設分類 & 食料品 & 日用品 & 複合商業 & コンビニ & \begin{tabular}{|l|} 
銀行 \\
\end{tabular} & 郵便局 & 内科 & 整形外科 & 歯科 & 眼科 & 三次救急 & 消防署 & 警察署 & バス停 \\
\hline 平均距離 & 1.0 & 1.5 & 1.7 & 1.4 & 2.8 & 1.6 & 2.2 & 3.5 & 2.2 & 4.4 & 10.8 & 3.7 & 2.1 & 0.7 \\
\hline 中央値距離 & 0.7 & 1.0 & 1.2 & 1.0 & 1.8 & 1.3 & 1.3 & 1.9 & 1.2 & 2.7 & 11.0 & 3.1 & 1.8 & 0.6 \\
\hline P圏距離 & 1.7 & 2.4 & 2.6 & 2.0 & 4.1 & 2.6 & 3.0 & 4.9 & 3.2 & 6.1 & 13.9 & 5.3 & 3.2 & 1.2 \\
\hline 最大距離 & 7.8 & 8.1 & 13.0 & 9.2 & 13.7 & 12.1 & 19.7 & 26.2 & 18.1 & 26.4 & 35.1 & 10.8 & 9.7 & 6.5 \\
\hline
\end{tabular}




\section{3、GIS を用いた居住環境分析}

\section{1 各施設を中心としたアクセス距離と距離帯別人口分布}

図 3 に各分野の施設から代表して 6 施設の距離帯別人口と累積比 率を示す。これは $500 \mathrm{~m}$ 毎の距離帯における人口分布を示している. ただし, 視覚的明瞭さを考えて $10 \mathrm{~km}$ 以上の人口を省略している.また, 表 2 に施設ごとの距離動向を示す.

購買分野の食料品店と複合商業施設を見比べると, 近距離でアク セス可能な人口割合が大きいのは食料品店であるが，複合商業施設 の $\mathrm{P}$ 圈および最大距離は食料品店のそれと, 距離の差が比較的少な いことがわかる (表 2)，複合商業施設の施設数は食料品店のおよそ 1/4であることから, 多くの人口をカバーする立地状況が確認できる. 生活財務分野の銀行は近距離でアクセス可能な人口は少なく，広域 に分布しているのがわかる。医療分野の内科は距離減衰傾向を示し てはいるが，10km以上での人口集積がみられ，地区レベルでの距離 的格差が存在していると考えられる. 安全分野の消防に関しては $2 \mathrm{~km}$ から $5 \mathrm{~km}$ 間でのまとまった人口分布がみられ，最大で $10 \mathrm{~km}$ 程度に収 まっている．消防のサービス提供圈に関しては後述する．交通分野 のバス停に関しては近距離でアクセス可能な人口比率が大きく，中 央值の距離が $600 \mathrm{~m}$ と徒歩圈内で利用できる人口割合が $50 \%$ であるこ とがわかる。

\subsection{T 人口と P 圏外人口からみた地区ごとの居住環境の特徵}

本節では，地区毎に距離と人口との関係の詳細を分析する．表 3 には地区ごとにみた T 人口，表 4 には地区ごとにみた $\mathrm{P}$ 圈外人口を 示寸．図 4 は距離帯 $500 \mathrm{~m}$ 毎に $20 \mathrm{~km}$ まで色分けした市域に，施設立 地と T 圈, $\mathrm{P}$ 圈，P 圈外人口分布を図示したものである。ここでは食 料品店と銀行, 内科, 第三次救急医療, 消防署について図示寸る. これら図表から地区ごとの居住環境の特徴を分析する。

\section{A : サービス利用者側からみる施設のアクセシビリティ}

\section{A-1 購買（食料品店, 日用品店, 複合商業施設, コンビニエンスス} トア)

まず，購買施設全体で共通していることは，T人口についてはいず れも [黒磯] 地区が最も高い值をとる．最も低い值をとるのはいず れも [高林］地区である．P 圈外人口では，いずれも [高林］地区が 最も大きい值を示す.

食料品店では，T人口が 8,797 人 $(45.1 \%)$ という值から, 約半数の 高齢者が徒歩圈での施設利用が可能であることを示している．また， $\mathrm{P}$ 圈外人口では [高林］地区が最大值を示し，徒歩圈に居住する高齢
者は 27 人と極めて少ない状態である. P 圈外人口が最も少ないのは ［塩原］地区となっている（図 4-1）。

日用品店では, T 人口は食料品店の次に多い. P 圈外人口は［高林］ 地区に約 $1 / 3$ が集中している.特徴的なのは[西那須野］地区で, [高林] 地区の次に P 圈外人口が大きい值を示しているところであり，その ほとんどは農業用地となっている地域（農村部）に集中寸る.

複合商業施設とコンビニエンスストアでは，T人口は「高林」地 区で共に 0 人である. 特徴的なのはコンビニエンスストアにおける $\mathrm{P}$ 圈外人口が購買施設の中で最小であることである. 表 1 において, コンビニエンスストアの施設数は食料品店の $1 / 3$ 以下であることか ら，多くの人口をカバーする施設立地の良さが窥える.

\section{A-2 生活財務（銀行，郵便局）}

銀行では，T 人口は [高林，篣根，鍋掛］地区に施設が立地してい ない理由から值は 0 人を示す。また，[西那須野］地区において最も 高い值を示寸．P 圈外人口は，[鍋掛］地区では施設が無いにも関わ らず 601 人と比較的小さい值を示しており，隣接する [黒磯］地区 の影響が現れていると考えられる. 地区の格差が顕著であり, [高林, 篣根，鍋掛]地区に $\mathrm{P}$ 圈外人口の偏在がみられる (図 4-2).

郵便局では，T 人口は [黒磯］地区で最大值をとる．P 圈外人口に おいて，市街地の［西那須野］地区で最大值を示しているのが特徴 的である。また，最小值は［塩原］地区である。

\section{A-3 医療（内科，整形外科，歯科，眼科，第三次救急）}

医療施設全体で共通していることは，T人口では第三次救急医療施 設を除いて [高林，塩原，篣根，鍋掛］地区において小さい值を示 していることがわかる．市街地である [黒磯，西那須野］地区では 比較的大きい值を示し, 医療分野における地域間格差を顕著に表し ている。 [塩原］地区では全ての施設において $\mathrm{T}$ 人口は 0 人， $\mathrm{P}$ 圈外 人口では当該地区の全高齢者人口（1,032人）を示している.さらに, 居住地から医療施設までのアクセス距離は最短で $8.6 \mathrm{~km}$ となってお りアクセシビリティが極端に低いことがわかる.

内科では P 圈が $3.0 \mathrm{~km}$ であり，P 圈外人口のほとんどは [ 黒磯，西 那須野，東那須野] 地区以外の農村・山間部に集中していることが わかる (図 4-3)。[塩原］地区に関しては，図 4-3 に示された P 圈 外人口がそのまま地区人口となっており，アクセシビリティの極端 な低さが確認できる。また，眼科に関しては施設が市全体で 4 箇所 しか存在せず，全体の $\mathrm{T}$ 人口は 1,130 人と極端に少なくなっている. 第三次救急医療施設に関しては隣町の医療施設が役割を担ってい

\begin{tabular}{|c|c|c|c|c|c|c|c|c|c|c|c|c|c|c|c|}
\hline \multirow{3}{*}{ 地区 } & \multirow{3}{*}{$\begin{array}{c}\text { 高齢者 } \\
\text { 人口 }\end{array}$} & \multicolumn{14}{|c|}{ T人口 } \\
\hline & & \multicolumn{4}{|c|}{$\begin{array}{c}\text { 購買 } \\
\end{array}$} & \multicolumn{2}{|c|}{ 生活財務 } & \multicolumn{5}{|c|}{ 医療 } & \multicolumn{2}{|c|}{ 安全 } & 交通 \\
\hline & & 食料品 & 日用品 & 複合商業 & コンビニ & 銀行 & 郵便局 & 内科 & 整形外科 & 歯科 & 眼科 & 三次救急 & 消防署 & 警察署 & バス停 \\
\hline 市全体 & 19,523 & $8,797(45.1)$ & $6,803(34.8)$ & $4,628(23.7)$ & $5,262(27)$ & $3,002(15.4)$ & $3,424(17.5)$ & $5,333(27.3)$ & $2,984(15.3)$ & $5,562(28.5)$ & $1,130(5.8)$ & \multirow{8}{*}{$\begin{array}{c}\text { いずれも } \\
0\end{array}$} & $361(1.8)$ & $1,773(9.1)$ & $1,0218(52.3)$ \\
\hline 高林 & 1,636 & $27(1.7)$ & $0(0.0)$ & $0(0.0)$ & $0(0.0)$ & $0(0.0)$ & $0(0.0)$ & $48(2.9)$ & $48(2.9)$ & $0(0.0)$ & $0(0.0)$ & & $48(2.9)$ & $0(0.0)$ & $368(22.5)$ \\
\hline 塩原 & 1,032 & $487(47.2)$ & $334(32.4)$ & $32(3.1)$ & $222(21.5)$ & $117(11.4)$ & $107(10.3)$ & $0(0.0)$ & $0(0.0)$ & $0(0.0)$ & $0(0.0)$ & & $163(15.8)$ & $50(4.9)$ & $717(69.5)$ \\
\hline 籉根 & 1,328 & $330(24.9)$ & $158(11.9)$ & $129(9.7)$ & $171(12.9)$ & $0(0.0)$ & $169(12.7)$ & $67(5.0)$ & $0(0.0)$ & $131(9.8)$ & $0(0.0)$ & & $0(0.0)$ & $107(8.1)$ & $657(49.5)$ \\
\hline 鍋掛 & 1,108 & $135(12.1)$ & $71(6.4)$ & $68(6.1)$ & $80(7.2)$ & $0(0.0)$ & $66(6.0)$ & $36(3.3)$ & $0(0.0)$ & $65(5.9)$ & $0(0.0)$ & & $0(0.0)$ & $17(1.5)$ & $364(32.9)$ \\
\hline 西那須野 & 6,797 & $3,337(49.1)$ & $2.426(35.7)$ & $2,055(30.2)$ & $2,008(29.5)$ & $1.494(22.0)$ & $1,193(17.6)$ & $2,216(32.6)$ & $1,257(18.5)$ & $1,989(29.3)$ & $244(3.6)$ & & $92(1.3)$ & $673(9.9)$ & $3,119(45.9)$ \\
\hline 東那須野 & 1,920 & $682(35.5)$ & $522(27.2)$ & $249(12.9)$ & $574(29.9)$ & $83(4.3)$ & $139(7.3)$ & $549(28.6)$ & $85(4.4)$ & $478(24.9)$ & $142(7.4)$ & & $0(0.0)$ & $215(11.2)$ & $1,070(55.8)$ \\
\hline 黒磯 & 5,702 & $3,799(66.6)$ & $3,291(57.7)$ & $2,096(36.8)$ & $2,207(38.7)$ & $1,308(22.9)$ & $1,749(30.7)$ & $2,417(42.4)$ & $1,594(28)$ & $2,899(50.8)$ & $744(13.0)$ & & $58(1.0)$ & $710(12.5)$ & $3,921(68.8)$ \\
\hline
\end{tabular}

表 4 地区ごとにみた P 圏外人口 ※（）内は地区人口に対する $\mathrm{P}$ 圏外人口の\%割合

\begin{tabular}{|c|c|c|c|c|c|c|c|c|c|c|c|c|c|c|c|}
\hline \multirow{3}{*}{ 地区 } & \multirow{3}{*}{$\begin{array}{c}\text { 高齡者 } \\
\text { 人口 }\end{array}$} & \multicolumn{14}{|c|}{ P人口 } \\
\hline & & \multicolumn{4}{|c|}{ 購買 } & \multicolumn{2}{|c|}{ 生活財務 } & \multicolumn{5}{|c|}{ 医療 } & \multicolumn{2}{|c|}{ 安全 } & 交通 \\
\hline & & 食料品 & 日用品 & 複合商業 & コンビニ & 銀行 & 郵便局 & 内科 & 整形外科 & 歯科 & 眼科 & 三次救急 & 消防署 & 警察署 & バス停 \\
\hline 市全体 & 19,523 & $3,897(20.0)$ & $3,903(20.0)$ & $3,893(19.9)$ & $3,885(19.9)$ & $3,889(19.9)$ & $3,902(20.0)$ & $3,903(20.0)$ & $3,858(19.8)$ & $3,901(20.0)$ & $3,903(20.0)$ & $3,902(20.0)$ & $3,883(19.9)$ & $3,889(19.9)$ & $3,899(20.0)$ \\
\hline 高林 & 1,636 & $1,262(77.1)$ & $1,427(87.2)$ & $1,335(81.6)$ & $1,241(75.8)$ & $1,588(97.1)$ & $906(55.4)$ & $1,035(63.3)$ & $1,166(71.3)$ & $1,236(75.6)$ & $1,561(95.4)$ & $1,520(92.9)$ & $1,214(74.2)$ & $817(49.9)$ & $731(44.7)$ \\
\hline 塩原 & 1,032 & $250(24.2)$ & $326(31.5)$ & $448(43.4)$ & $420(40.7)$ & $175(16.9)$ & $175(16.9)$ & $1,032(100.0)$ & $1,032(100.0)$ & $1,032(100.0)$ & $1,032(100.0)$ & $1,032(100.0)$ & $80(7.7)$ & $265(25.7)$ & $157(15.2)$ \\
\hline 鍋掛 & 1,108 & $443(40.0)$ & $431(38.9)$ & $340(30.7)$ & $444(40.1)$ & $601(54.2)$ & $508(45.9)$ & $468(42.3)$ & $395(35.7)$ & $313(28.2)$ & $263(23.7)$ & $256(23.1)$ & $498(45.0)$ & $250(22.6)$ & $258(23.3)$ \\
\hline 西那須野 & 6,79 & $656(9.6)$ & $762(11.2)$ & $0(4.9)$ & $563(8.3)$ & $10(0.1)$ & $989(14.6)$ & $308(4.5)$ & & $346(5.1)$ & & $0(0.0)$ & $472(7.0)$ & $1,429(21.0)$ & $1,920(28.3)$ \\
\hline 東那須野 & 1,920 & $385(20.1)$ & $202(10.5)$ & $525(27.3)$ & $274(14.3)$ & $151(7.9)$ & $568(29.6)$ & $120(6.3)$ & $96(5.0)$ & $220(11.4)$ & $0(0.0)$ & $0(0.0)$ & $421(21.9)$ & $347(18.1)$ & $244(12.7)$ \\
\hline & & & & & & & $000(20.0)$ & & $30(0.0)$ & & & & $164(2.9)$ & $276(4.8)$ & $\frac{244(12.1)}{374(66)}$ \\
\hline
\end{tabular}


る. P 圈は $13.9 \mathrm{~km}$ である.ここで救急医療機関の救命時間に基づき 30 分以内 ${ }^{24)}$, 注 8 ) の到達圈を想定した場合, 医療圈は $15 \mathrm{~km}$ となり（図 4-4), 現状でP 圈より多くの人口をカバーしている. しかし，医療 圏の外れに位置する [高林, 塩原］地区について救急医療体制に課 題が残る。特に [塩原] 地区では医療分野の環境が整っていないため, 医療体制および救急医療体制の見直しが求められる.

\section{A-4 交通（バス停）}

バス停に関しては，T 人口において最小值を示すのは［鍋掛］地区 である. P 圈外人口では [西那須野] 地区で最大值を示しているが, そのほとんどは農村部に集中している。
B : サービス提供者側からみる施設のアクセシビリティ B-1 安全 (消防署, 警察署)

二施設の $\mathrm{P}$ 圈外人口についてみると，消防署では［高林，篣根］ 地区で多くみられ，警察署では［高林，西那須野］地区で多くみら れる。

消防署の P 圈は $5.3 \mathrm{~km}$ である. 消防署が役割を担う防災・救急体 制の提供圈を署から現場到着までの所要時間に基づき 10 分以内 ${ }^{24)}$, 注 8) を想定した場合，防災・救急圈は $5 \mathrm{~km}$ となり，P圏と大差はない（図 4-5). 現状の防災・救急体制において問題がみられる地域は［高林, 篣根］地区であり，地区人口に対する $\mathrm{P}$ 圈外人口の割合は共に 7 割

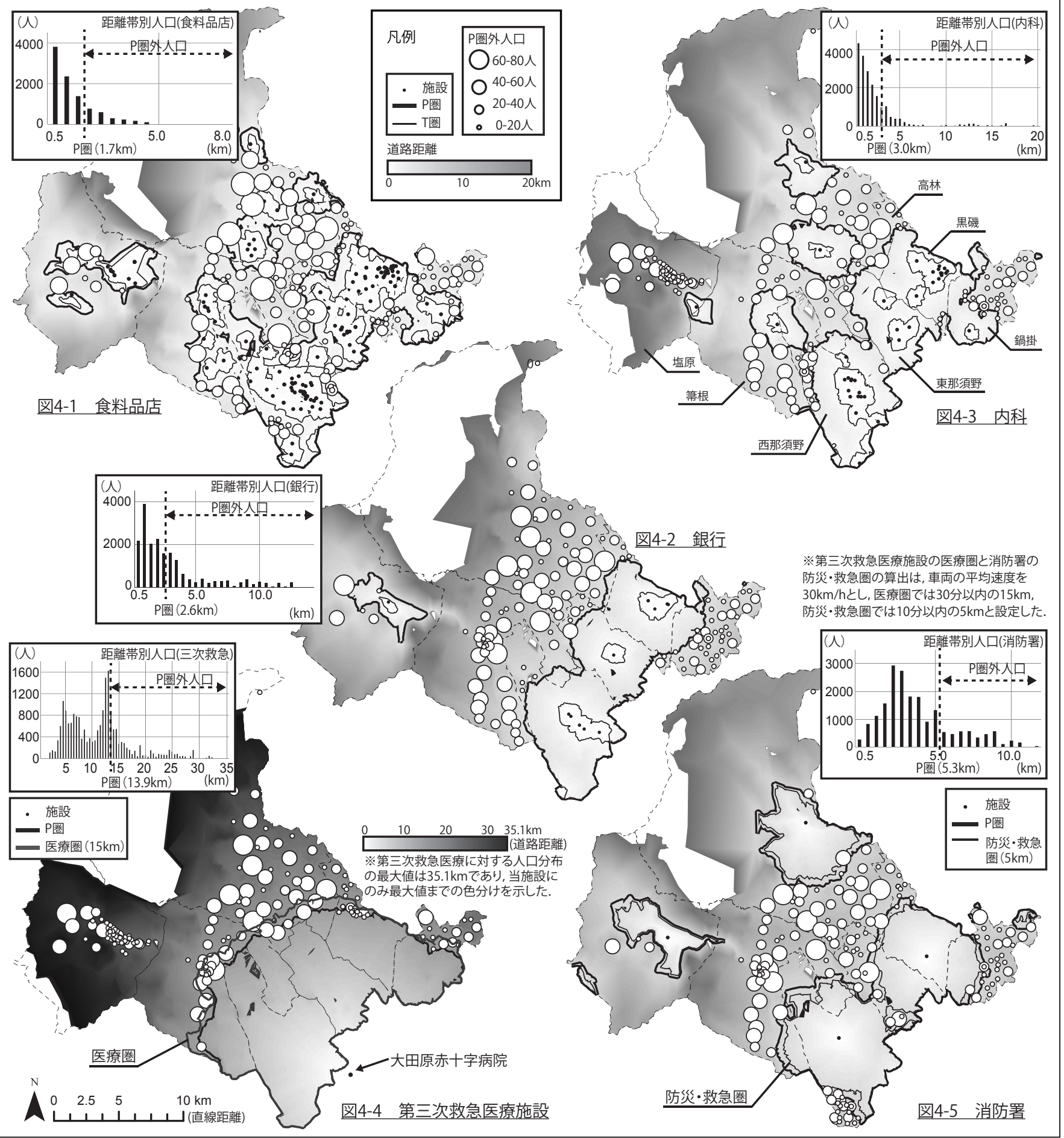

図 4 アクセシビリティマップ上でみた距離圏域およびP 圏外人口 
以上であり，これらの地域における提供体制を見直していく必要が あると考える。

以上より，全体的にみて生活関連施設へのアクセシビリティが高 いのは, 市街地を形成し人口が多く,さらに高齢化率が低い［黒磯, 西那須野, 東那須野］地区である. 特に [黒磯］地区は多くの施設 が集中し, ぞの分野の施設においても $\mathrm{T}$ 人口は大きい值を示し，P圈 外人口は小さい值をとっている. [西那須野] 地区は, [黒磯]地区 ほどではないが比較的アクセシビリティが高いと言える。ただし， バス停に関しては P 圈外人口において大きい值をとる。P圈外人口の 多くは農村部に集中し，高齢者にとって重要な交通手段であるバス の利用に関して問題点が明らかになった。市街地近郊の [東那須野] 地区は平均的な值を示している.

アクセシビリティが低いのは, [鍋掛, 高林, 篣根, 塩原] 地区である.

特に［高林］地区では全分野においてアクセス距離の大きさが目立
つ. [塩原］地区では医療施設へのアクセシビリティが最も低い現状 にある．ただし，［塩原］地区では食料品店や日用品店の T 人口にお いて比較的大きい值を示しているが，これは山間部という地理的条 件のもと線形状の比較的集中した居住形態であるという理由からで あると考えられる。 また，バス停の T 人口が地区の高齢者人口の約 7 割を占めており，バスの有効活用が重要であると考える。[鍋掛］地 区に関しては，T 人口で小さい值を示しつつ P 圈外人口でも農村・山 間部の [ 高林，篣根，塩原］地区に比べて小さい值をとっているの が特徴的である。これは隣接する [黒磯］地区に集中する施設の影 響によるものと考えられる. ただ, [黒磯, 西那須野, 東那須野] 地 区に比べてアクセシビリティが低いのは顕著である.

4. アクセシビリティの地域内格差

当該市では農村・山間部と市街地部とで生活関連施設へのアクセ
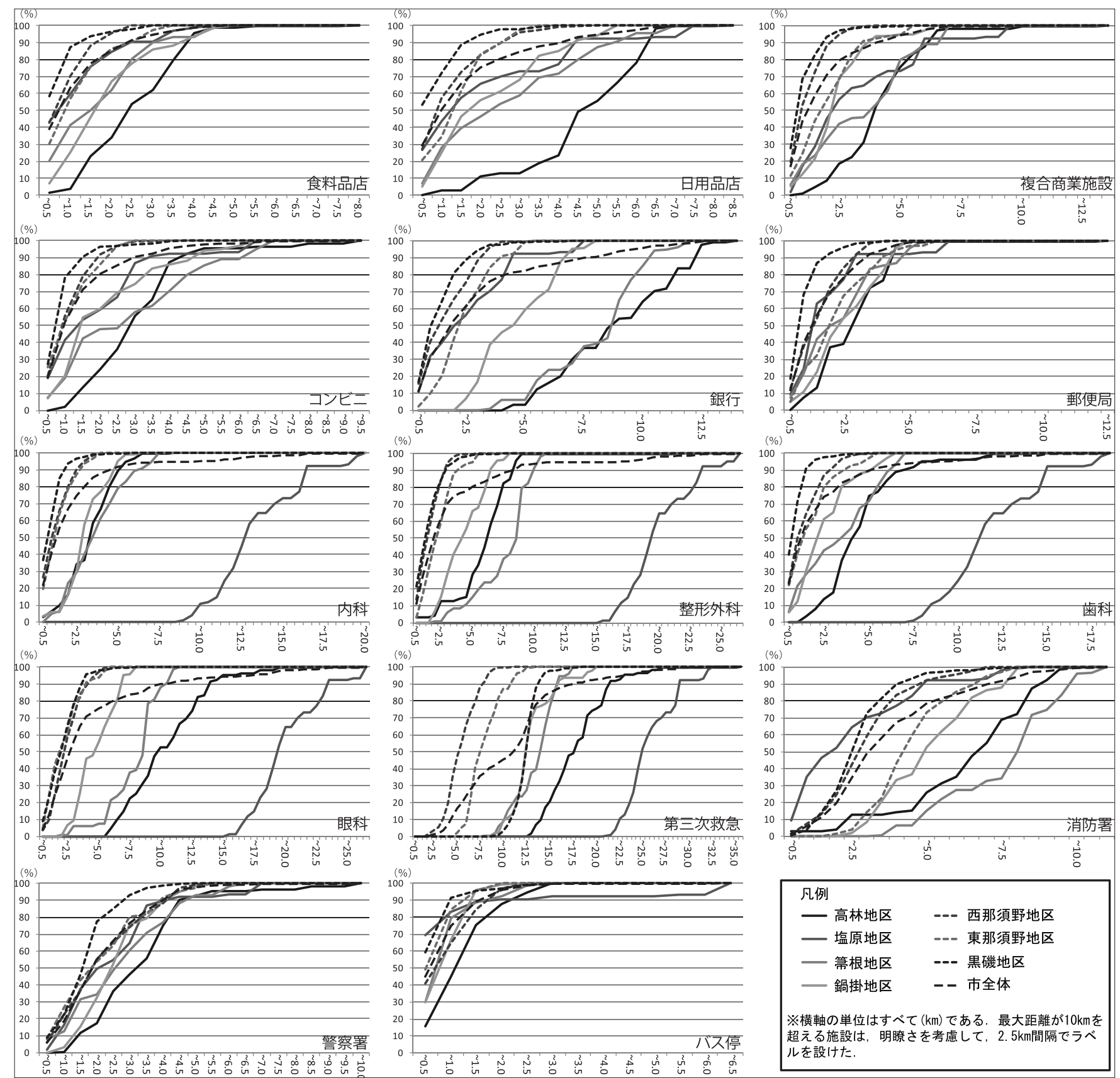

\begin{tabular}{|c|c|}
\hline \multicolumn{2}{|l|}{ 凡例 } \\
\hline 一 高林地区 & --- 西那須野地区 \\
\hline 一 塩原地区 & --- 東那須野地区 \\
\hline 一 箒根地区 & --- 黒磯地区 \\
\hline 一 鍋掛地区 & - - 市全体 \\
\hline $\begin{array}{l}\text { ※榼える軸の単位はす } \\
\text { ルを施設は, 明 } \\
\text { ルを設けたた. }\end{array}$ & 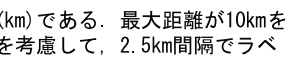 \\
\hline
\end{tabular}

図 5 施設ごとの地区別距離帯別人口の累積率 
シビリティの高さに偏りがあることがわかった。ここでさらに，ア クセシビリティの偏在, つまり地域内格差の程度を明確にするため に, 施設ごとの地区別距離帯別人口の累積率（図 5) を示し, その特 徵をみていく. 地区別の累積率のグラフ（以下，累積曲線）のばら つきが大きくなるほどアクセシビリティの地域内格差（以下, 地域 内格差）が大きくなると考える. ばらつきの大きさは, 累積曲線に おいて, 距離帯ごとに地区別の累積率の標準偏差を求注8), 平均的 に標準偏差の大きい施設をばらつきの大きい施設とした（図 6).表 5 にその結果を示す.

全体的な傾向として, 図 5 の点線で示した [ 黒磯, 西那須野, 東 那須野] 地区の累積曲線の形状が類似しており, ばらつきは小さい. そのため, 表 5 に示寸標準偏差の平均值が大きくなれば, 市街地部 と農村・山間部における地域内格差も大きいと言える.

サービス利用者側からみた施設については, 表 5 において, 食料 品店, 郵便局, バス停で相対的に平均值が低く地域内格差が小さい. 郵便局に関しては計画的な施設配置が行われている結果であると考 える，バス停に関しても徒歩圈利用を想定したバス停の計画的配置 の結果であると考える. また, 食料品店に関しては, 施設数が多く 人口カバー率が高いためと言える。逆に, 地域内格差が大きいのは 医療施設であり, 相対的に平均值が高い.この原因の一つとして, 図 5 からわかるように [ 塩原 ] 地区においてアクセス距離が大きく なり，標準偏差は高くならざるを得ない，そこで，[塩原］地区を除 外して標準偏差を算定した結果（表 5 の平均'）は, 全ての医療施設 で平均值が低くなる。特に内科と歯科では地域内格差が小さい.

サービス提供者側からみた施設については, 警察署で相対的に平 均值が低く地域内格差が小さい。一方で, 消防署は医療施設に次い で平均值が高く地域内格差が大きい。

以上より，市街地部と山間・農村部におけるアクセシビリティの 地域内格差を確認した。特に格差が大きいのは医療施設であり, 施 設の適正配置の検討が必要である ${ }^{25)}$, 注 10$)$ 。ただし， [ 塩原］地区に 限定された課題であると捉えられるため, 地域の実態に即した対策 が求められる.アクセシビリティが低い地区では人口集積が小さく, 経済面での影響を考えると, サービス提供方法が人口規模の観点か ら限定されることを考慮する必要がある。このようなアクセシビリ ティが低く人口集積が小さい地域では, 移送サービスや訪問系サー

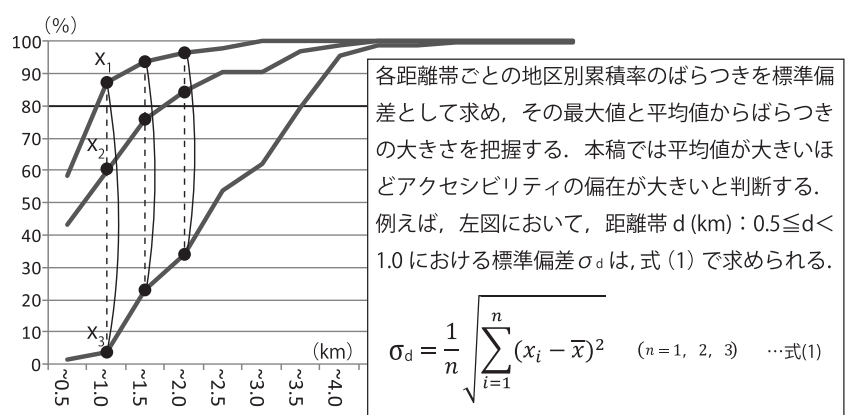

図 6 ばらつきの計算方法

表 5 標準偏差の最大値と平均値

※複商：複合商業施設，整形：整形外科

\begin{tabular}{|c|c|c|c|c|c|c|c|c|c|c|c|c|c|c|c|}
\hline & 食料品 & 日用品 & コンビニ & 複商 & 郵便 & 銀行 & 内科 & 歯科 & 整形 & 眼科 & 三次救急 & 警察 & 消防 & バス停 & ※最大'と平均'は各医療施設に関して [ 塩原 ] \\
\hline 最大 & 26.0 & 28.3 & 24.3 & 28.0 & 23.5 & 40.8 & 35.7 & 35.3 & 41.3 & 44.7 & 40.6 & 17.9 & 33.1 & 17.3 & 地区を除外した場合の計算結果である. 医療 \\
\hline 平均 & 8.0 & 14.8 & 9.2 & 8.9 & 5.2 & 21.9 & 21.9 & 20.6 & 25.8 & 25.9 & 21.0 & 5.6 & 18.4 & 5.0 & 施設において累積曲線のばらつきが大きい \\
\hline 最大' & $*$ & $*$ & $*$ & $*$ & $*$ & $*$ & 33.3 & 28.7 & 38.4 & 42.4 & 42.1 & * & $*$ & ** & [ [ 塩原 ] 地区を除けば，内科，歯科では標準 \\
\hline 平均' & $*$ & * & * & * & $*$ & $*$ & 5.8 & 7.1 & 9.5 & 13.0 & 13.2 & $*$ & $*$ & $*$ & 偏差の平均值が小さくなりアクセシビリティ \\
\hline
\end{tabular}

ビス等の施設立地に頼らないサービス提供方法よってカバーする必 要があると考える．また，医療施設に次いで地域内格差が大きい消 防署については, 救急医療体制の観点などから医療機関と連動した サービス提供体制の見直しが必要であると考えられる.

\section{5. 結論}

本研究では, 地方都市における高齢者の居住環境を生活実態に即 した道路ネットワークを用いてアクセシビリティの観点から明らか にした。第 3 章において, 地区ごとに $\mathrm{T}$ 人口と $\mathrm{P}$ 圈, $\mathrm{P}$ 圈外人口を指 標として分析を行い，現状では農村・山間部のアクセシビリティが 低い傾向にあり, 市街地部との相対的なアクセシビリティの地域内 格差があることを定量的に示した。

距離帯別人口の累積率のばらつきからアクセシビリティの地域内 格差を分析した第 4 章では, 地域内格差が小さい生活関連施設とし てバス停, 郵便局などが挙げられ, 地域内格差が大きい生活関連施 設は医療施設であることを示した。今後の居住環境整備の方向とし ては, 高齢者の徒歩生活圈に配虑すると, 分析で示したように, 徒 歩でのアクセシビリティが高い既存の公共交通（バス）を利用した 移動手段を推進することが現実的であると考えられる．また，アク セシビリティの低い医療施設に関して言えば，新たに病院をつくる のではなく, 比較的遠方からの患者でも確実に受け入れ可能かつ適 切な処方を行えるシステムを整備することが既存資源の持続可能性 につながる. 加えて, アクセシビリティの低い地域に対するケアが 必要であり，施設立地に頼らないサービス提供方法の構築が必要だ と考える。その取り組みの一例として, 買い物と連携した看護音一 ビスの提供事例が見られる ${ }^{26)}$. これは, 総合病院が移動販売と連携し, 看護宅配便として移動販売利用者の健康相談や診療情報等のアドバ イスを行うことで，医療・看護サービスの過不足地域におけるニー ズを満たそうとする先進的なモデルである，今後，このようなソフ 卜面での取り組みが適切に評価され, 施設整備に依存しない居住環 境整備としての有效性が証明されることが重要である.

今後の課題として, 第一に, 今回のような居住環境の分析のみで は，施設数や立地状況だけでなく取り扱う物品やサービスなどの利 用者が選択時に考慮する「質」という部分が十分に反映できていな い，そのため，施設立地状況とニーズや居住者の経済的な観点など を関連付けた分析が求められる. 具体的には, 本研究で一括して扱っ た食料品店に関して言えば，購買頻度や施設規模，取り扱う品物の 種類・数を加味した分析をすることで, 日常の買い物利便性に関す るアクセシビリティの地域差はより明確になると考えられる。 また, 移動販売や訪問サービスなどのサービス提供者側の視点を含めた分 析・評価も必要となる.

第二に, 本研究は, 徒歩圈または高齢者人口 $80 \%$ の充足を指標之 したアクセシビリティの地域差の分析に留まるが，地域包括ケアシ ステムの構築が急がれている今日, 高齢者のアクセシビリティを適 切に評価し, 移動困難者などに対する移送サービス等の生活支援に 向けた居住環境評価の指標の構築が必要であると考える. 
第三に，本研究では，GIS 上で実態に即した分析を行うために，基 本単位区集計の人口分布, 街区・地番レベルの施設立地, 実際の道 路ネットワーク情報を扱っているが，より実空間を反映した分析が 必要である. 高齢者の居住地の特性を反映した人口分布や施設立地 の精度の向上，移動手段別に利用される道路の種類や幅員等を反映 した分析，さらに地形的な高低差を取り入れた分析など，より詳細 なデータを用いた分析手法を今後継続して行っていく必要がある.

注

注 1)ここでの「居住環境」は，建物内部空間の環境ではなく，外部空間の環 境を意味している。

注 2) 平成 12 年度, 平成 17 年度, 平成 22 年度の 3 時点の国勢調査デー夕を基 に作成. 平成 12 年時点では那須塩原市は, 黒磯市, 西那須野町, 塩原町 に分かれていたため,これら 3 地域のデータを結合して用いた。

注 3）本研究で扱う食料品店は, 主に商店街などを形成する商店などの小規模 店舖を指寸，近年コンビニやロードサイドなどの複合商業施設の台頭に より，その機能が縮小しつつある商店街の店舗などの地域居住に密接に 関係する食料品店が，高齢者の居住環境にどの程度残っているのかとい うことを意識し設定した。

注 4) バス路線は各バス停から生活利便施設までの経路や到達時間, 本数など に差異があるため, 厳密にはそれらを考慮したアクセシビリティ分析が 必要であるが, 本研究では簡易的に居住地からバス停までの距離のみを 考慮し分析を行う。

注 5）生活実態に即した分析を行うには，厳密には生活関連施設の建物位置を 把握する必要があるが, 現時点では情報公開に限界があり困難である. 本研究では, 簡易的かつ正確に施設の緯度・経度情報を街区・地番レ心゙ ルで取得できる CSVアドレスマッチングサービスを利用した。

注 6) 基本単位区集計は, 農村部や山間部などの人口集積が小さい居住地の位 置の精度は低下寸る可能性があり，3 章以降の分析結果に影響があると考 えられる。 その影響について確認するためには, 実際の人口分布と基本 単位区集計の人口分布の精度を検証する必要があるが, 現時点では困難 であり検証方法を模索中である.

注 7) 徒歩での移動の場合, 幅員が大きくなると渡る場所が限られ迂回が生じ る可能性がある.また同様に, 自動車での移動の場合, 幅員の大きさによっ て生活上の主要道路がある程度限定される可能性があるが, それらは考 慮せず概算の徒歩・自動車での移動について算定をした。

注 8）消防庁の報告 ${ }^{24)}$ によると, 現場到着から病院収容までの時間は 30 分弱 となっており, 本研究では扱いやすい数值として 30 分を設定した. また, 同報告では, 覚知から現場到着までの時間は 8 分強となっており, 本研 究では扱いやすい数值として 10 分を設定した。共に車両の速度を $30 \mathrm{~km} /$ $\mathrm{h}$ とし換算した.

注 9）本研究では, グラフのばらつきを求める際に, 簡易的な方法としてグラ フの縦軸に着目し標準偏差を算定しているが，厳密には縱横の両軸から の標準偏差を算定するなどして, 正確にグラフのばらつきを算定する必 要があると考える.

注 10）医療機関の選択では，物理的な距離の近さだけではなく，医療機関の質 (設備, 技術, 人間関倸等) も重要な選択要素となるため ${ }^{25}$, 厳密にはそ れらを考慮した医療機関の適正配置の検討が必要である.

\section{参考文献}

1) 厚生労働省：「平成 26 年版高齢社会白書」

http://www8. cao. go. jp/kourei/whitepaper/index-w. html, 2013.2.10 参 照

2) 国立社会保障 -人口問題研究所 : 将来推計人口・世帯数

http://www. ipss. go. jp/index. asp, 2013.2.10 参照

3）厚生労働省：地域包括ケアシステム

http://www. mhlw. go.jp/stf/seisakunitsuite/bunya/hukushi_kaigo/ kaigo_koureisha/index.html, 2013.2.10 参照

4) 市田登, 三浦朋恵, 佐藤栄治, 本庄宏行, 三橋伸夫, 藤本信義：高齢者の 生活実態に即した見守り体制構築に向けた基礎的研究 3 地方都市の実態
調査に基づく検討, 日本建築学会計画系論文集, 77, 672, pp.369-375, 2012.2

5）徳田哲男：高齢者の外出環境条件の整備に関する研究-立地条件の違い による外出阻害要因の抽出-, 福祉のまちづくり研究, 1(2), pp.2-9, 1999. 12

6) 白石るり，陳晨，本間里見，位寄和久，両角光男：大牟田市における高齢 者支援のための民間地域交流施設の配置計画に関寸る研究，日本建築学会研 究報告，九州支部，計画系 (51)，pp. 593-596，2012.3

7）貞広幸雄 : 都市人口分布と店舗分布の比例関係についての考察, 日本建築 学会計画系論文報告集, 432, pp. 99-104, 1992.2

8）森永武男, 有馬隆文, 萩島哲, 坂井猛：生活利便施設の分布から見た生 活環境に関する研究, 都市計画, 別冊, 都市計画論文集 35, p p.991-996, 2000. 10

9）内原英貴, 吉川徹 : コンパクトシティからみた地方都市の人口社会増減の 分布と生活利便性の関連分析 - 浜松市と金沢市を例として - , 日本建築学会 計画系論文集，74，642，pp. 1805-1811，2009.8

10）腰塚武志, 大澤義明: 距離分布による施設配置の分析, 都市計画, 別冊 (18), pp. 25-30, 1983. 11

11）降旗徹馬，松岡公二：利用者の分布を考慮した施設配置分析，GIS- 理論と 応用, Vol.2, No. 1, pp. 91-99, 1994

12）尾崎尚也，大澤義明：移動距離の平等性及び効率性からみた公共施設配置 の評価, 日本建築学会計画系論文集，563，pp. 131-138，2003.01.30

13）増山篤：商業・医療施設へのアクセシビリティと高齢者の居住パターンと の関係 - 千葉県浦安市を対象とした実証分析一, 都市計画論文集, 42 (2), pp. $72-79,2007.10$

14）山岸輝樹, 鈴木雅之, 広田直行, 服部岑生 : 住宅地の生活利便性の評価に よる高齢者の暮らしの比較研究 -ライフエリア法を用いた建築的市街地整備 手法の基礎的研究 2-, 日本建築学会計画系論文集, 78, 686, pp.801-806, 2013. 4

15）佐藤栄治，三橋伸夫：地方都市における高齢者の継続居住可能性に関寸る 研究 - 宇都宮市を事例とした居住環境評価-, 日本建築学会計画系論文集, 78, 691, pp. 1965-1972, 2013.9

16）讃岐亮，佐藤栄治，鈴木達也，吉川徹，牧紀男：避難場所としての商業施 設の立地ポテンシャル評価 - 紀伊半島の食料を供する施設を対象として-, 日本建築学会計画系論文集，78，692，pp. 2127-2134，2013.10

17) 讃岐亮, 佐藤栄治, 熊川寿郎, 鈴木達也, 吉川徹: 地上搬送のアクセシビリティ の視点から見た三次救急医療体制, 日本建築学会大会学術講演梗概集, 都市 計画, pp. 127-128, 2013.8.30

18）那須塩原市：「第 5 期那須塩原市高齢者福祉計画」

http://www. city. nasushiobara. lg. jp/212/2797/index. html, 2013. 2. 10 参照

19）那須塩原市：「都市計画マスタープラン」

http://www. city. nasushiobara. 1g. jp/31/275/001329. htm1, 2013.2.10 参照

20）上杉昌也, 浅見泰司: 社会経済的観点から見た施設立地と近隣居住地人口 構成との空間的関係 - 東京都区部における商業施設の店舗類型と所得分布の 関係 -, 都市計画論文集, 49 (3), pp. 351-356, 2014. 10

21）讃岐亮，吉川徹，佐藤栄治：地域施設までの道路距離の精度に対して人口 の集計単位がもたら寸影響 - 神奈川県の小地域を対象としてー, 日本建築学 会計画系論文集，75，658，pp. 3011-3019，2010.12

22）東京大学空間情報科学研究センター, CSV アドレスマッチングサービス http://newspat. csis.u-tokyo. ac. jp/geocode/, 2013.1.10 参照

23）日本建築学会：建築設計資料集成-人間 丸善株式会社 2003

24）総務省消防庁：「平成 25 年度版 救急・救助の現況」 http://www. fdma. go.jp/neuter/topics/fieldList9_3.html, 2014.2.15 参 照

25）椎野亜紀夫，中村攻，木下勇，齋藤雪彦：既成住宅地における高齢者の生 活管理外出の圏域特性に関する研究，ランドスケープ研究論文集 19, 815820,2001

26) 浅井秀子, 熊谷昌彦：中山間地域における買い物弱者対策に関する取り組 み一鳥取県江府町の事例一, 日本建築学会技術報告集, 20,44, p p. 269272, 2014. 2 


\title{
A STUDY ON THE EVALUATION METHODOLOGY OF LIVING ENVIRONMENT FOR THE ELDERLY PEOPLE IN LOCAL CITY
}

Analysis of regional structure from the point of view of facilities for daily living

\author{
Yasuhiro NOHARA* , Eiji SATOH** and Nobuo MITSUHASHI ${ }^{* * *}$ \\ * Grad. Stud., Graduate school of Engneering, Utsunomiya Univ., M.Eng \\ ** Assoc. Prof., Graduate school of Engneering, Utsunomiya Univ., Dr.Eng \\ *** Prof., Graduate school of Engneering, Utsunomiya Univ., Dr.Eng
}

Introduction

In recent years, residential areas in local city are facing many problems; rapidly increasing number of elderly people, regional gaps of social service and shrinking social capital. Increasing needs of the elderly in demographic change have an effect on medical and health-care system, public service providing. For solving these problems, these areas urgently need to consider for keeping livelihood, creating a safe and secure society for elderly people. The purpose of this study is to obtain the knowledge about the assessment methodology of present environmental condition in residential area. And the methodology will be able to judge the future situation whether the region will be habitable.

Methods

We analyze the characteristics of the local, Nasushiobara city in Tochigi, by using of GIS. To calculate the road distance analyze quantitatively the accessibility of local areas to the facilities related to livelihood; grocery, health-care center, bank, post office, etc. So we clarify the spatial disparity. So we consider the possibility area of livelihood by foot and how to provide the many services for area of elderly, by use of the data of the living environment .

We set up "Population of T" that denotes the population in the area within walking distance, and set up "The area of P" and "The population of outside the area of $\mathrm{P}$ " that denotes the divided threshold of majority or minority, the majority is indicated by $80 \%$ of the accumulated population that is added up the population in order of distance from closest to the facilities. "The area of P" indicates the utility circle of majority, and "The population of outside the area of P" is indicated by population of minority that consists of the other $20 \%$. We see the accessibility of the elderly and the population, and try to assessment the present environmental condition in residential area.

Results

As the results of the GIS analysis, we made sure of distribution of the accessibility between the urban area and the agricultural and mountain area. And we clarified the characteristics of every district of the city. The most accessible facility is "bus-stop", and the agricultural and mountain area have relatively low accessibility. The worst accessible facility is "medical institution", especially in Shiobara area, most of the elderly are "Population of P". Distribution of accessibility in regard to police station and post office is low. It is considered that because of public planned facility location.

Conclusion

The agricultural and mountain area of the city not has an adequate amount of facilities within walking distance and the accessibility is low. We think that the city needs to promote policy to effectively use the existing assets. Especially, it's important that the city promotes to use the existing local bus network within walking distance for the future. And we have to care of the area of low accessibility, by constructing of the service providing method does not rely on the facility location. We need the assessment of software approach to construct the method such as it.

（2014 年 11 月 10 日原稿受理, 2015 年 10 月 15 日採用決定) 